Nama : Jordhie Tanarubun

NRP : $\quad 130117126$

KP : $\quad \mathrm{A}$

Artikel Review :

\begin{abstract}
Paper ini bertujuan untuk memahami bagaimana penerapan Global Value Chain dalam industri rotan di indonesia serta hambatan dan peluang yang dialami oleh petani, produsen, dan desainer dalam penerapan Global Value Chain, serta menjelaskan mengenai International Alliance Strategy dan alasan perusahaan multinasional memilih salah satu dari lima alternative strategy yang ada, yaitu: (1) The Wholly Owned Subsidiary With Contractual Collaboration, (2) The Wholly Owned Subsidiary With The Licence Agreement, (3) The International Trade With The Licence Agreement, (4) Joint Venture And (5) Outsourcing (Pratono \& Ratih, 2019).
\end{abstract}

\title{
I. Global Value Chain
}

Global Value Chain merupakan konsep di mana sebuah barang atau jasa diproduksi oleh beberapa negara atau kawasan ekonomi, sehingga membutuhkan kemampuan dan kemauan untuk berbagai nilai tambah yang memungkinkan semua pelaku mendapatkan manfaat yang adil. Konsep ini berbeda dengan konsep keunggulan kompetitif di mana sebuah perekonomian harus menguasai pasar input, pasar output, industri pendukung, hingga menciptakan persaingan (Pratono, 2019). Jelaskan penerapan konsep Global Value Chain dalam industri rotan :

Pada tahun 1980-an GVC memberikan peluang kepada para petani rotan, yang pada awalnya sulit untuk bertemu dengan pembeli internasional secara langsung. Pada tahun 1987, pemerintah Indonesia mulai berhenti mengekspor produk rotan mentah dan mendorong petani rotan untuk mengubah rotan menjadi produk yang bernilai lebih agar para petani dapat 
memperoleh manfaat yang lebih. Namun pada tahun 2008 terjadi krisis keuangan global yang menyebabkan pemerintah Indonesia pada saat itu melarang ekspor rotan yang bertujuan mendukung konservasi hutan dan menghidupkan kembali industri rotan. Sebelum kebijakan tersebut diberlakukan di Indonesia terdapat lebih dari 1.129 eskportir dengan nilai ekspor sebesar \$ 370 juta per tahun. Selama kebijakan larangan ekspor, sekitar 40 persen mentah bahan rotan diselundupkan (Myers, 2015). Kebijakan yang berfokus pada perlindungan sumber daya terkait dengan teori ekonomi pembangunan (Dang dan Pheng, 2015). Teori tersebut berpendapat bahwa negara-negara miskin perlu mengubah struktur ekonomi mereka dari pertanian sektor ke sektor industri sebagai sumber utama untuk pertumbuhan ekonomi.

Karena kebijakan tersebut beberapa perusahaan internasional mulai mengakuisisi atau mendirikan pabrik mereka di Cirebon, seperti beberapa varietas rotan yang diekspor sebelumnya bahkan tidak digunakan oleh produsen Indonesia.

Pada saat krisis ekonomi global, agen penjualan dan produsen melakukan strategiwait and see sementara para produsen rotan menghentikan produksinya dalam jangka waktu yang tidak ditentukan, dalam fase ini para produsen tersebut memberikan peluang kemitraan seperti pengembangan produk desainer baru dan sebagainya.

Studi ini menyoroti bahwa kemitraan antara perusahaan terkemuka dan lokal desainer untuk mengembangkan inovasi kreatif, dalam hal ini produsen hanya fokus pada penjualan dan desainer akan fokus ke hal seni sehingga inovasi dapat ditranformasikan menjadi penjualan. Hal tersebut mengkonfirmasi bahwa transisi ekonomi memungkinkan perusahaan untuk mengubah efisiensi menjadi inovasi sebagai pendorong utama untuk kesuksesan mereka (Ding et al., 2016).

Dengan adanya pembagian kerja ini akan menyebabkan peningkatan besarbesaran dalam perdagangan dan investasi internasional yang memperluas industri diluar batas negara (Linqing \& Liwen, 2011) 


\section{International alliance strategy}

Partnership antara perusahaan lokal dengan multinasional bisa dilakukan dengan lima alternative strategy: (1) the wholly owned subsidiary with contractual collaboration, (2) the wholly owned subsidiary with the licence agreement, (3) the international trade with the licence agreement, (4) joint venture and (5) outsourcing (Pratono \& Ratih, 2019). Jelaskan alasan bagi sebuah perusahaan asing dalam memilih salah satu strategi tersebut :

Bagi sebuah sebuah perusahaan asing yang ingin menjalin partnership dengan sebuah perusahaan lokal, Joint Venture merupakan salah satu strategi yang tepat. Strategi ini dikenal sebagai aliansi ekuitas, yang cenderung menarik perusahaan target yang lebih menguntungkan (Kim dan Palia 2014). Joint Venture merupakan salah satu jenis aliansi strategis yang ditandai oleh kepemilikan bersama, tata kelola bersama, dan kinerja bersama. berdasarkan pengertian tersebut banyak banyak kemudahan yang dapat diperoleh oleh perusahaan asing maupun perusahaan lokal, selain itu keuntungan yang diperoleh perusahaan multinasional yaitu memperluas produksi di negara ini dengan sumber daya minimum untuk mempertahankan biaya pada tingkat minimum serta dapat mengandalkan perusahaan lokal untuk mengurusi berbagai peraturan yang meliputi, lisensi e-katalog (Pratono \& Ratih, 2019), sementara itu bagi perusahaan lokal Joint Venture merupakan langkah awal bagi perusahaan lokal dalam mengembangkan perusahaannya menjadi perusahaan multinasional. Dengan adanya Joint Venture, distribusi nilai yang adil tidak hanya meningkatkan hubungan modal jaringan dan bentuk pemerintahan yang positif tetapi juga tidak sempurna kinerja yang muncul dari umpan balik multilateral (Kano 2017). Hubungan yang berfungsi dengan baik antara pemangku kepentingan lokal menciptakan struktur untuk jaringan bangunan, yang mungkin menentukan penerimaan merek oleh pelanggan dan pemegang saham (Tarnovskaya dan Biedenbach 2016). 


\section{Bibliography}

Pratono, A. H. (2019). Cross-cultural collaboration for inclusive global value chain: a case study of rattan industry. International Journal of Emerging Markets, https://doi.org/10.1108/IJOEM-01-2017-0028.

Pratono, A. H., \& Ratih, R. S. (2019). International Alliance Strategies: A Case Study of the Indonesian Medical Device Industry. Globalization and Development, 381-400.

Myers, R. (2015). What the Indonesian rattan export ban means for domestic and international markets, forests, and the livelihoods of rattan collectors, Forest Policy and Economics, Vol. 50 No. 1, pp. 210-219.

Dang, G. and Pheng, L. (2015), Theories of Development Economics, Springer, New York, NY.

Ding, Y., Malleret, V. and Velamuri, S.R. (2016),"Institutional complexity and the strategy behaviors of SMEs in transition environments", International Journal of Emerging Markets, Vol. 11 No. 4, pp. 514-532.

Linqing, L., \& Liwen, T. (2011). Two-dimensional Governances and Industrial International Competitiveness. Nankai Business Review International, 2(3), 325-344.

Kim, T.-N., \& Palia, D. (2014). Private equity alliances in mergers. Journal of Empirical Finance, 27, 10-20.

Kano, L. (2017). Global value chain governance: A relational perspective. Journal of International Business Studies, 48(6), 1-22.

Tarnovskaya, V., \& Biedenbach, G. (2016). Multiple stakeholders and B2B branding in emerging markets. Qualitative Market Research, 19(3), 287-309. 